\title{
Spectrophotometric Determination of Bismuth with Alizarin Red S and Cetylpyridinium Chloride - Application to Water Samples, Urine and Veterinary Preparation
}

\author{
Salim A. Mohammed Mohammed M. Mohammed \\ Department of Chemistry \\ College of Science \\ University of Mosul
}

(Received 14/10/2012;Accepted 7/1/2013)

\begin{abstract}
A simple, accurate, sensitive and reliable method for spectrophotometric determination of Bismuth(III) is developed. The method is based on the reaction of bismuth (III) with alizarin red S (ARS) and cetylpyridinium chloride (CPC) in the presence of Triton $\mathrm{X}-100$ at $\mathrm{pH} 3$ to form a pink, water soluble ternary complex which shows maximum absorption at $507 \mathrm{~nm}$ with a molar absorptivity of $1.4 \times 10^{4} \mathrm{~L}_{\mathrm{mol}} \mathrm{m}^{-1} \mathrm{~cm}^{-1}$. The calibration curve is linear in the concentration range $5-150 \mu \mathrm{g}$ of bismuth (III) in a final volume of $20 \mathrm{ml}$ (i.e. $0.25-7.5 \mu \mathrm{g} \mathrm{ml}^{-1}$ ) with a determination coefficient of $\left(\mathrm{R}^{2}\right)(0.9974)$. The limit of detection (LOD) and the limit of quantification (LOQ) are 0.0671 and $0.2235 \mu \mathrm{g} \cdot \mathrm{mL}^{-1}$, respectively. Under optimum conditions, the stoichiometry of the reaction between bismuth (III), alizarin red S and cetylpyridinium chloride is found to be 1:3:6, respectively. The recoveries are obtained in the range of $98.8-102.1 \%$ and a relative standard deviation (RSD) of \pm 0.93 to $\pm 3.07 \%$ depending on the concentration level. The proposed method has been applied successfully to the determination of bismuth (III) in various samples such as, natural waters, urine and veterinary preparation.
\end{abstract}

Keywords: Bismuth(III) determination, Alizarin red S, Cetylpyridinium chloride, Spectrophotometry.

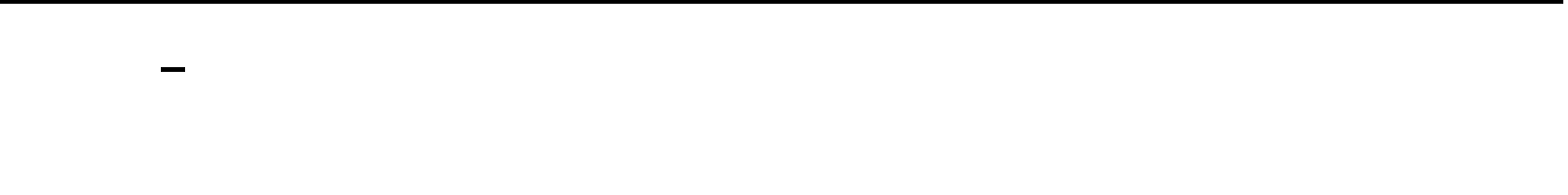

\section{wald}

قم ظويرطريقةطيفية بسطة ودقيقة ومسلسة ومعتمدة لقدير البزموث (III ). تعتمد الطريقة على

تقاعل البزموث مع كلثف الاليزارين الأحمر لس وعولمل للشد للططهيسيتل كلوريد البرين وترايتون 100-X في وسط حلمضي (pH 3) لتكوين معقد ثلاثي ذي لون وردي ذائب في الماء يطى أعلى

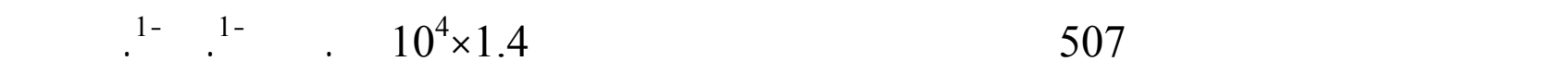
حدود قانون بير ت̈طق ضمن مدى التركيز 5 - 150 مايكروغرله من البزموث (III) في حجم نهائي 20 


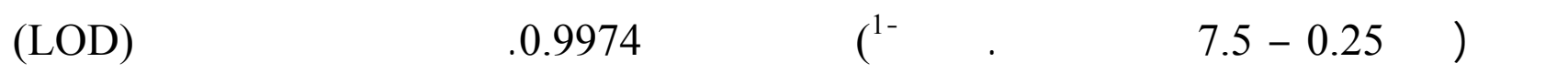
و حد القدير الكه (LOQ ) للطريقة 0.0671 و 0.2235 مايكروغرلم مللتر -1 على التوالي، في حين كلت قيم نسبة الإسترجاع تتراوح بين 98.8 و 102.1\% والانحرف القيلسي النسب( و 3.07\% اعتمادا على مستوى التركيز للبزموث وان نسبة الفاعل بين البزموث (III ) والاليزارين

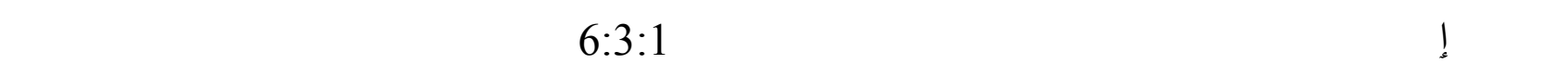

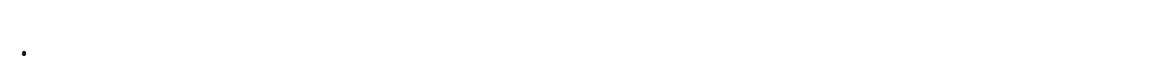
الهاملت الدالة: بزموث (III )، الاليزارين الأحمر لس،سيتل كلوريد البربن،طيفي.

\section{INTRODUCTION}

Bismuth is found in the earth's crust up to $0.0002 \%$. It is widely used in the form of oxides, carbonates and sulfides in nature (Didi et al., 2011). It is used in producing malleable iron and as a catalyst for making acrylic fibers. The metal is also used as a thermo coupling material and has found application as a carrier for $\mathrm{U}^{235}$ or $\mathrm{U}^{233}$ fuel in nuclear reactors (Chandrashekhar and Mansing, 2008). Bismuth and its compounds are used in semiconductors, cosmetic preparations, alloys and metallurgical additives (Afkhami et al., 2006 ; Yamini et al., 2002). Bismuth compounds have been used in medicine for more than 200 years in a variety of gastrointestinal disorders, because of their demulcent properties. Bismuth and its compounds are used in the treatment of syphilis and gastric disorders especially for colitis, diarrhea and peptic ulcers. They were and still are used for burn bandage dressings, antiseptic powders, and in the treatment of venereal diseases (Yamini et al., 2002 ; Barakat, 2002). A number of toxic effects in humans have been attributed to bismuth compounds, such as nephrotoxic, neurotoxic, kidney damage symptoms nephropathy, osteoarthrapathy, hepatitis and neuropathology. As the uses of bismuth in medicine increases, it has spread in the environment and the chance of exposure of organisms to bismuth has been increased, therefore, the determination of bismuth in the environmental and biological samples is important (Afkhami et al., 2006). Various analytical techniques, such as chemiluminometric method (Al-Hakeem and Shakir, 2008), derivative spectrophotometry (Gumus et al., 2005), resonance light scattering (Cui et al., 2007), potentiometric stripping analysis ( Nayan et al., 2010), hydride generation-atomic fluorescence spectrometry (HG-AFS ) (Ling et al., 2005), inductively coupled plasma atomic emission spectrometry (ICP-AES) (Araki et al., 2008), stripping voltammetry (Amir and Karel, 2012), graphite furnace atomic absorption spectrometry (GFAAS) (Yamini et al., 2002), square wave voltammetry (SWV) (Hasdemir and Karaboduk, 2010) and amperometry (Reddy and Reddy, 2010) were used for its measurement. Many spectrophotometric methods have also been used for the determination of bismuth in various samples due to their simplicity, rapidity and wide applications, for this purpose widely used reagents such as xylenol orange (Jeronimo et al., 2004), 1,2-diaminocyclohexaneN,N,N,N-tetraacetic acid(DACT) (Jan et al., 2007), 4-(2-benzotholylazo)-2,2biphenyl diol (BTABD) (Amin, 2011), di-(hydrogenated tallow alkyl)dimethylammonium chloride (Barakat, 2002), 1-amino-4,4,6-trimethyl $(1 \mathrm{H}, 4 \mathrm{H})$ pyrimidine-2-thiol ( Gaikwad et 
al., 2005), bromopyrogallol red in the presence of Triton X-114 (Afkhami et al., 2006 ), methyl thymol blue (Tzanavaras et al., 2004), and pyrocatechol violet (PCV) (Honova et al., 1988) were proposed some of these methods suffer from several disadvantages, such as, the use of heating step, low range of determination, critical working conditions, no applications, time consuming and poor selectivity. Other methods are typically less sensitive, relatively complicated, or require ion exchange, solvent extraction and expensive instrumentation. In this work, a detailed investigation of the bismuth (III)-ARS reaction has been carried out in the presence of cetylpyridinium chloride and Triton X-100 to increase the sensitivity of the method and to explore its applicability.

\section{Apparatus}

\section{EXPERIMENTAL}

All absorption spectra and absorbance measurements were carried out by a Shimadzu UV-160 double beam UV-visible spectrophotometer (Japan) with matched 1-cm quartz cells. While all $\mathrm{pH}$ measurements were recorded by using HANNA $211 \mathrm{pH}$ meter.

\section{Reagents}

All chemicals used are of highest purity available.

Stock bismuth (III) solution (1000 $\left.\boldsymbol{\mu g} \cdot \mathrm{ml}^{-1}\right)$. This solution is prepared by dissolving $0.2312 \mathrm{~g}$ of $\mathrm{Bi}\left(\mathrm{NO}_{3}\right)_{3} .5 \mathrm{H}_{2} \mathrm{O}$ (Fluka) in $3 \mathrm{ml}$ of $5 \mathrm{M}$ nitric acid and diluted to the mark with distilled water in a $100-\mathrm{ml}$ volumetric flask .

Working bismuth solution( $\left.100 \mu \mathrm{g} \cdot \mathrm{ml}^{-1}\right)$. It is prepared by diluting $10 \mathrm{ml}$ of the stock solution of bismuth to $100 \mathrm{ml}$ with distilled water in a volumetric flask.

Alizarin red S (ARS) $\left(\mathbf{1} \times \mathbf{1 0}^{-\mathbf{3}} \mathbf{M}\right)$. This reagent is prepared by dissolving $0.0342 \mathrm{~g}$ of ARS (Fluka) in $100 \mathrm{ml}$ distilled water using a volumetric flask. The solution is then transferred to a brown bottle and remained stable for at least one week.

Buffer solution (pH 3). It is prepared by mixing $50 \mathrm{ml}$ of $0.1 \mathrm{M}$ potassium hydrogen phthal- ate with $22.3 \mathrm{ml}$ of $0.1 \mathrm{M} \mathrm{HCl}$ and the volume is diluted to $100 \mathrm{ml}$ with distilled water (Perrin and Dempsey, 1974) using a volumetric flask.

Composite mixture solution. This solution is prepared by dissolving $0.8805 \mathrm{~g}$ of ascorbic acid (BDH) with $0.0210 \mathrm{~g}$ of sodium fluoride (Fluka) in about $40 \mathrm{ml}$ distilled water. The $\mathrm{pH}$ of the resulting mixture is adjusted to 3 with $0.1 \mathrm{M} \mathrm{HNO}_{3}$ solution and the volume is then completed to $50 \mathrm{ml}$ with distilled water using a volumetric flask. This solution is freshly prepared.

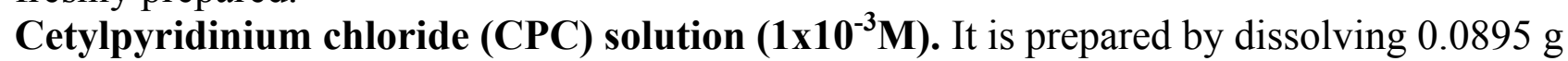
of CPC (Koch-Light) in $250 \mathrm{ml}$ distilled water.

Solution of triton X-100 (1\%). This is also prepared by dissolving $1 \mathrm{~g}$ of Triton $\mathrm{X}-100$ (Fluka) in $100 \mathrm{ml}$ distilled water.

\section{Recommended procedure and calibration graph}

A suitable aliquot containing $5-200 \mu \mathrm{g}$ of Bi(III) was transferred into $20-\mathrm{ml}$ calibrated flask and mixed with $2 \mathrm{ml}$ of $1 \times 10^{-3} \mathrm{M}$ ARS reagent, $5 \mathrm{ml}$ of $1 \times 10^{-3} \mathrm{M} \mathrm{CPC}$ solution, $1 \mathrm{ml}$ of

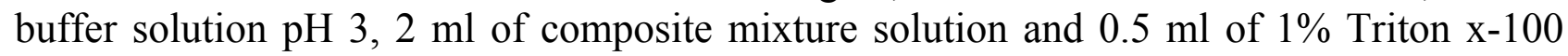
solution. The mixture is mixed and completed to the mark with distilled water and its absorbance is measured at $507 \mathrm{~nm}$ against a blank solution prepared in the same manner but without bismuth. 


\section{Procedure for human urine}

The sample of urine is digested as follows (Afkhami et al., 2006 ). In a $100 \mathrm{ml}$ beaker, $25 \mathrm{ml}$ of urine sample accurately measured, then treated with a mixture of $5 \mathrm{ml} \mathrm{H}_{2} \mathrm{O}_{2}$ and $2.5 \mathrm{ml}$ of concentrated $\mathrm{HNO}_{3}$, and is placed on a hot plate. The sample is moderately heated and evaporated almost to dryness. Thereafter, fresh portion of $2.5 \mathrm{ml}$ of concentrated $\mathrm{HNO}_{3}$ is added to the residue and heated to dryness. The residue is dissolved in $2.5 \mathrm{ml}$ of $1 \mathrm{M} \mathrm{HCl}$ and the $\mathrm{pH}$ of the resulting solution is adjusted to 3.0 with $0.1 \mathrm{M} \mathrm{NaOH}$ and diluted to $25 \mathrm{ml}$ with distilled water. A suitable aliquot of this solution is pipeted out into a $20 \mathrm{ml}$ calibrated flask and the bismuth content is determined as in the recommended procedure.

\section{Procedure for dosage form (veterinary sample)}

The content of 3 sachets of Diaclean containing $2000 \mathrm{mg}$ bismuth subnitrate are weighed. A quantity of powder equivalent to $0.01 \mathrm{~g}$ of bismuth is weighed and dissolved in $10 \mathrm{ml}$ of $2.5 \mathrm{M}$ nitric acid The solution is then shaken thoroughly, filtered and diluted with distilled water to $100 \mathrm{ml}$ in a volumetric flask. An aliquot of the diluted drug solution is then treated as done in the recommended procedure.

\section{RESULTS AND DISCUSSION}

The preliminary investigation showed that on mixing $100 \mu \mathrm{g}$ of bismuth (III) with excess of $1 \times 10^{-3} \mathrm{M}$ ARS reagent, $1 \mathrm{ml}$ of $1 \times 10^{-3} \mathrm{M}$ CPC solution, $2 \mathrm{ml}$ of $1 \%$ Triton X-100 solution and distilled water in a $20-\mathrm{ml}$ calibrated flask, a red ternary water soluble complex [Bi(III)-ARS-CPC] is observed and showed a maximum absorption at $501 \mathrm{~nm}$ against the corresponding reagent blank solution. This observation led us to the development of a sensitive method for the determination of bismuth based on a ternary complex formation. The effect of various parameters on the absorption intensity of the coloured complex is studied and reaction conditions have been optimized.

\section{Effect of pH}

The colour intensity of [Bi(III)-ARS-CPC] complex showed pH dependent absorption maximum at $507 \mathrm{~nm}$, whereas the reagent blank solution showed maximum absorption at $426 \mathrm{~nm}$. The optimum $\mathrm{pH}$ range for complex formation is 2.92-3.09 (Fig.1). $\mathrm{pH} 3$ is considered the optimum because of the high absorbance intensity and good colour contrast $(\Delta \lambda=83 \mathrm{~nm})$. Therefore, a $1 \mathrm{ml}$ of (potassium hydrogen phthalate $-\mathrm{HCl}$ ) buffer solution of $\mathrm{pH} 3$ is selected.

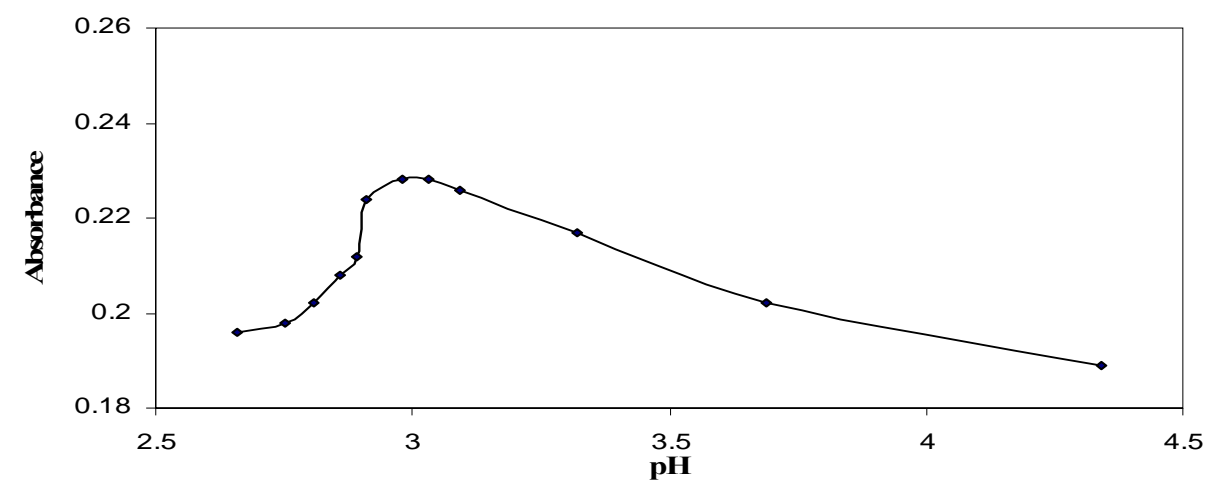


Fig. 1: Effect of pH on absorbance of [Bi(III)-ARS-CPC ] complex.

\section{Effect of reagent amount}

The influence of different amounts of the ARS reagent in the presence of CPC with respect to bismuth (III) on the formation of ternary complex is investigated. The experimental results indicated that a $2 \mathrm{ml}$ of $1 \times 10^{-3} \mathrm{M}$ ARS reagent can be considered optimum because of its highest colour sensitivity and lowest corresponding blank value.

\section{Effect of CPC and triton X-100 amounts}

The presence of Triton X-100 in the reaction mixture has been necessary in removing the slight turbidity formed in its absence. The effect of different amounts of various surfactants [cationic (CPC) and neutral (Triton X-100)] are studied for this purpose. The results listed in Table (1) show that $5 \mathrm{ml}$ of $1 \times 10^{-3} \mathrm{M}$ CPC and $0.5 \mathrm{ml}$ of $1 \%$ Triton X-100 solutions have been considered the optimum amounts and used for the subsequent experiments for the following: ( $\mathrm{i}$ ) turbidity of solution was disappeared and (ii) the colour contrast of the $\mathrm{Bi}(\mathrm{III})-\mathrm{ARS}$ reaction is improved. The experimental data reveal that cetyltrimethyl-ammonium bromide (CTAB) can also be used instead of CPC. Also, other neutral surfactants such as, between 20 has been tried but the results obtained were not as useful as those with Triton X-100.

Table 1: Effect of surfactants on absorbance.

\begin{tabular}{|c|c|c|c|c|c|}
\hline \multirow{2}{*}{${ }_{100}^{\text {Triton X- }}$} & \multirow[t]{2}{*}{ mL of $1 \%$} & \multicolumn{2}{|c|}{ Absorbance } & \multirow{2}{*}{$\begin{array}{c}\lambda_{\max } \\
(\mathrm{nm})\end{array}$} & \multirow{2}{*}{$\begin{array}{l}\Delta \lambda^{*} \\
(\mathbf{n m})\end{array}$} \\
\hline & & Sample & Blank & & \\
\hline 0.5 & 1 & Turbid & - & - & - \\
\hline 0.5 & 2 & Turbid & - & - & - \\
\hline 0.5 & 3 & Turbid & - & - & - \\
\hline 0.5 & 4 & 0.321 & 0.056 & 510 & 80 \\
\hline 0.5 & 5 & 0.334 & 0.034 & 507 & 80 \\
\hline 1.0 & 1 & 0.303 & 0.038 & 507 & 75 \\
\hline 1.0 & 2 & 0.327 & 0.043 & 507 & 77 \\
\hline 1.0 & 3 & 0.322 & 0.057 & 509 & 74 \\
\hline 1.0 & 4 & 0.317 & 0.050 & 508 & 76 \\
\hline 1.0 & 5 & 0.319 & 0.051 & 509 & 75 \\
\hline 1.5 & 1 & 0.308 & 0.033 & 505 & 70 \\
\hline 1.5 & 2 & 0.286 & 0.036 & 507 & 69 \\
\hline 1.5 & 3 & 0.285 & 0.036 & 505 & 72 \\
\hline 1.5 & 4 & 0.287 & 0.039 & 504 & 70 \\
\hline 1.5 & 5 & 0.283 & 0.044 & 505 & 72 \\
\hline
\end{tabular}

${ }^{*} \Delta \lambda$ : is the colour contrast $=\lambda_{\max } \mathrm{S}-\lambda_{\max } \mathrm{B}$, where $\mathrm{S}=$ sample, $\mathrm{B}=$ blank. 


\section{Effect of Masking agent on absorbance}

To evaluate the applicability of ARS reagent to the determination of bismuth, the effect of various masking agents which are usually used for interfering metal ions are studied. The results are shown in Table (2).

Table 2: Effect of masking agent on absorbance of $100 \mu \mathrm{g} / 20 \mathrm{ml} \mathrm{Bi(III)}$

\begin{tabular}{|c|c|c|c|c|}
\hline \multirow[t]{2}{*}{ Masking agents* } & \multicolumn{4}{|c|}{ Absorbance/ml. of masking agent } \\
\hline & 0.0 & 0.5 & 1.0 & 2.0 \\
\hline Ascorbic acid $(0.1 \mathrm{M})$ & \multirow{7}{*}{0.332} & 0.328 & 0.329 & 0.319 \\
\hline Tartaric acid $(0.01 \mathrm{M})$ & & 0.301 & 0.275 & 0.216 \\
\hline Succinic acid $(0.01 \mathrm{M})$ & & turbid & turbid & turbid \\
\hline 5-Sulphosalisylic acid (0.01M) & & turbid & turbid & turbid \\
\hline $\mathrm{NaF}(0.01 \mathrm{M})$ & & 0.334 & 0.341 & 0.336 \\
\hline EDTA $(0.01 \mathrm{M})$ & & 0.018 & 0.007 & 0.009 \\
\hline Nitrilotriacetic acid(NTA) $(0.01 \mathrm{M})$ & & 0.009 & 0.006 & 0.005 \\
\hline
\end{tabular}

- $\quad$ The $\mathrm{pH}$ of solutions are adjusted to 3.0.

The results in Table (2) indicate that ascorbic acid and $\mathrm{NaF}$ solutions have no effect on the absorbance of [Bi(III)-ARS-CPC] complex, while other masking agents exhibit decreasing in the absorbance owing to their complexing action with bismuth. Therefore, composite mixture solution containing (ascorbic $\operatorname{acid}(0.1 \mathrm{M})+\mathrm{NaF}(0.01 \mathrm{M}))$ ) is prepared and its effect on the absorbance of coloured complex is then examined. The experimental results showed that $2 \mathrm{ml}$ of the composite mixture solution is optimum and it was recommended for the subsequent experiment. The order of addition on the absorbance is also investigated. The experiments showed that the order of $(\mathrm{Bi}(\mathrm{III})+\mathrm{ARS}+\mathrm{CPC}+$ buffer solution + composite mixture solution + Triton X-100) at $507 \mathrm{~nm}$ is the optimum because of its high absorbance value.

\section{Effect of time on colour development}

To test the effect of time on the absorbance of the coloured complex at $507 \mathrm{~nm}$, the $\mathrm{Bi}(\mathrm{III})$ complex has been prepared from different amounts (50 and $100 \mu \mathrm{g}$ ) of $\mathrm{Bi}$ (III) under the optimal experimental conditions, the absorbance is measured at different time intervals up to $60 \mathrm{~min}$. Table (3) indicates that the colour of the complex develops immediately and the absorbance remains maximum and constant for at least 40 minutes.

Table 3: Effect of time on colour development of Bi(III) complex.

\begin{tabular}{|c|c|c|c|c|c|c|c|c|c|c|c|}
\hline $\begin{array}{c}\text { Bi(III) } \\
(\boldsymbol{\mu g})\end{array}$ & \multicolumn{10}{c|}{ Absorbance / min. } \\
\cline { 2 - 13 } & 0 & 5 & 10 & 15 & 20 & 25 & 30 & 35 & 40 & 50 & 60 \\
\hline $\mathbf{5 0}$ & 0.177 & 0.181 & 0.190 & 0.192 & 0.197 & 0.199 & 0.194 & 0.186 & 0.183 & 0.178 & 0.176 \\
\hline $\mathbf{1 0 0}$ & 0.347 & 0.349 & 0.349 & 0.347 & 0.341 & 0.334 & 0.330 & 0.326 & 0.328 & 0.318 & 0.319 \\
\hline
\end{tabular}




\section{Validity of Beer's law and reproducibility}

Under the optimum operating conditions, a linear calibration graph is obtained for 5$150 \mu \mathrm{g}$ of $\mathrm{Bi}(\mathrm{III})$ in a final volume of $20 \mathrm{ml}$ ( i.e., $0.25-7.5 \mu \mathrm{g} . \mathrm{ml}^{-1}$ ). Higher concentrations show a negative deviation from Beer's law (Fig. 2). The apparent molar absorptivity of the ternary Bi-ARS-CPC complex is $1.4 \times 10^{4} 1 . \mathrm{mol}^{-1} \mathrm{~cm}^{-1}$, which corresponds to Sandell's sensitivity index of $0.01492 \mu \mathrm{g} . \mathrm{cm}^{-2}$ of $\mathrm{Bi}(\mathrm{III})$. The limit of detection (LOD) is 0.0671 $\mu \mathrm{g} . \mathrm{ml}^{-1}$ and the limit of quantification (LOQ) is $0.2235 \mu \mathrm{g} \cdot \mathrm{ml}^{-1}$. The reproducibility of the procedure is studied by the analysis of three series of solutions (five identical samples for each series) having final bismuth concentration of $1.5,5$ and $7.5 \mu \mathrm{g} \mathrm{ml}^{-1}$. The results showed a relative standard deviation of 3.07, 0.94 and $0.93 \%$, respectively.

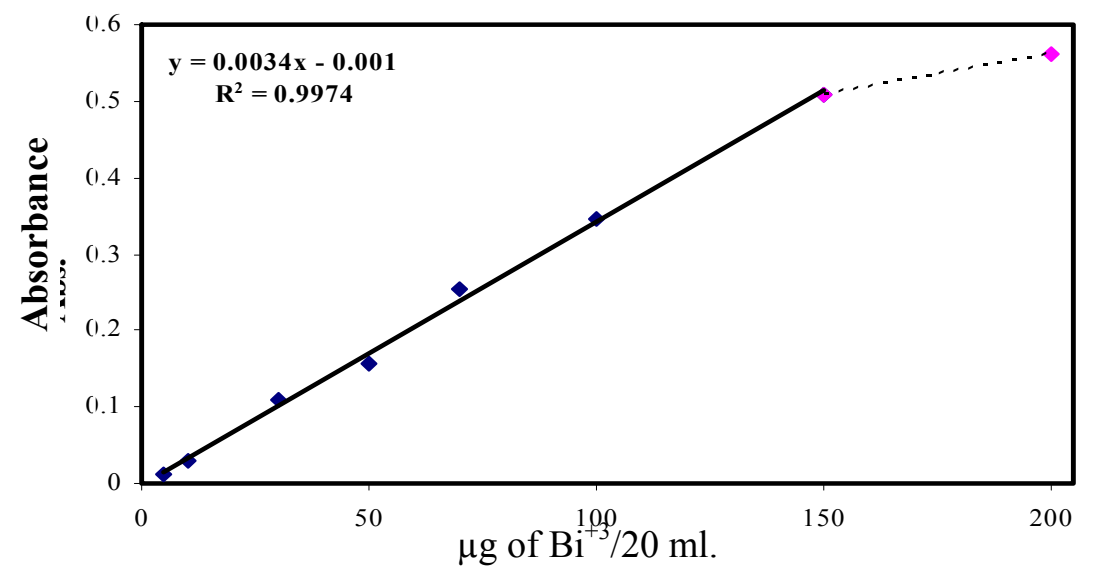

Fig. 2: Calibration graph for bismuth determination using the proposed method

\section{Final absorption spectra}

Under the above established optimized conditions, bismuth ion forms a red water soluble ternary complex with ARS and $\mathrm{CPC}$ at $\mathrm{pH} 3$ in the presence of composite mixture solution. The coloured complex exhibits one maximum absorption located at $507 \mathrm{~nm}$ against the reagent blank solution (Fig. 3).

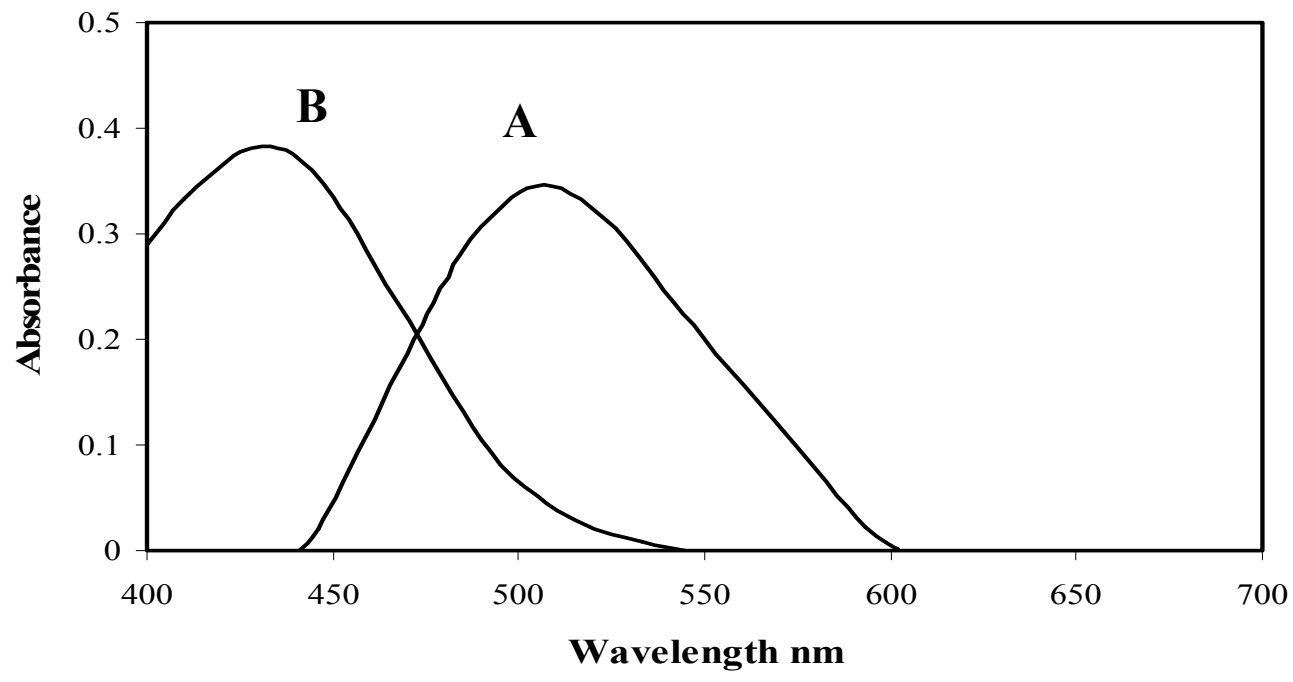


Fig. 3: The absorption spectra of $100 \mu \mathrm{g} \mathrm{Bi(III)/20} \mathrm{ml} \mathrm{(A)} \mathrm{against} \mathrm{blank} \mathrm{and}$ (B) blank against distilled water.

\section{Composition of the complex}

The stoichiometry of the complex is studied under the established conditions by applying the continuous variations method (Job's method) and mole-ratio method (Delevic, 1997). The experimental results in both methods (Fig. 4) show that the molar ratio of $\mathrm{Bi}(\mathrm{III})$ to ARS in the complex is found to be 1:3.The molar ratio of the Bi-ARS to CPC in the presence of Triton X-100 is also estimated and it was found to be 1:3:6, respectively. The stability constant of the coloured complex is also studied (Hargis, 1988) and it was found to be $2.47 \times 10^{13} \mathrm{M}^{-2}$.
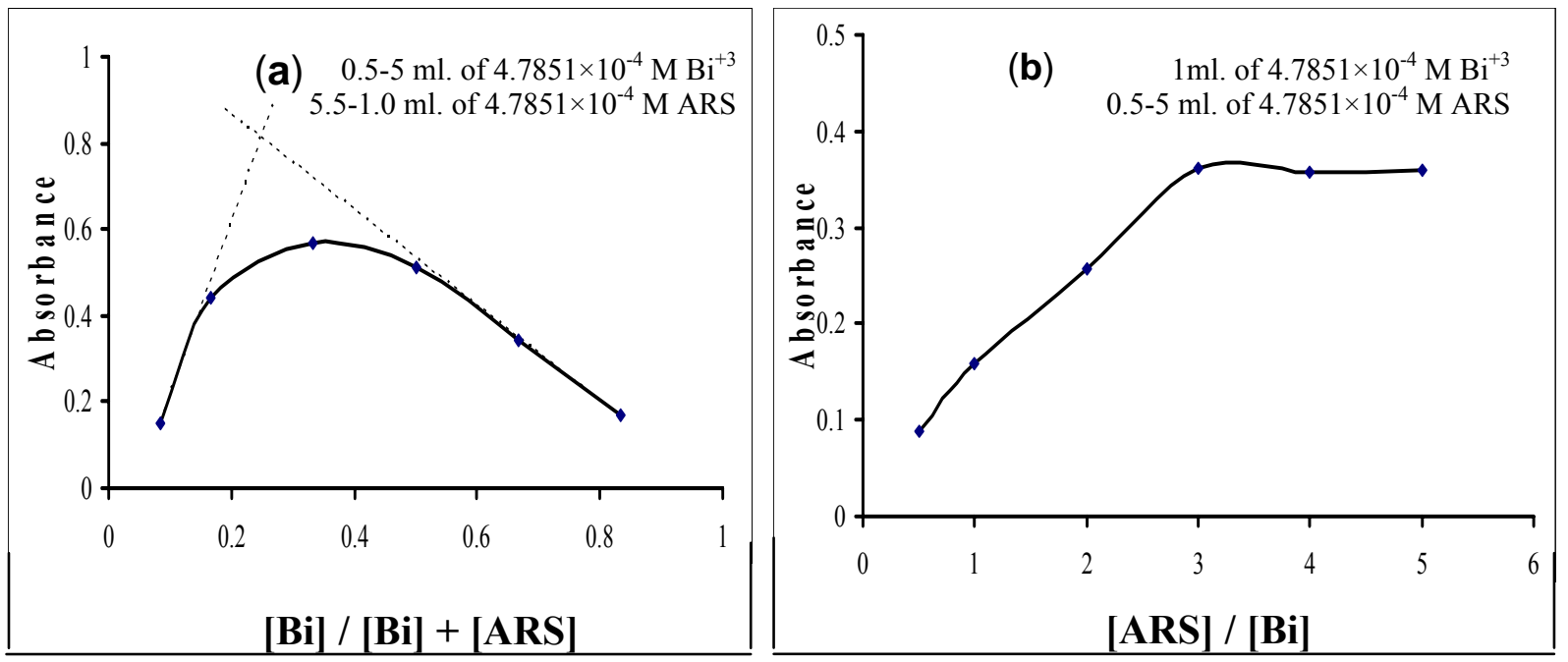

Fig. 4: (a) Continuous variations and (b) mole-ratio plots for Bi(III) - ARS complex.

\section{Effect of Interference}

The effect of interfering species on the determination of $100 \mu \mathrm{g} / 20 \mathrm{ml}$ bismuth was studied under optimum conditions with proposed method. As shown in Table 4, the largest interfering species are found to be $\mathrm{Al}^{3+}, \mathrm{Cr}^{3+}, \mathrm{Fe}^{3+}, \mathrm{Fe}^{2+}, \mathrm{Cd}^{2+}, \mathrm{Ni}^{2+}, \mathrm{Zr}^{4+}$ and $\mathrm{PO}_{4}^{-3}$ ions.

Table 4: Individual tolerance limit of foreign ions on the determination of $100 \mu \mathrm{g}$ of Bi(III)

\begin{tabular}{|l|c|}
\hline \multicolumn{1}{|c|}{ Foreign ions added } & Tolerance limit , $\mu \mathrm{g}$ \\
\hline $\mathrm{Na}^{+}, \mathrm{NO}_{3}^{-}$ & 1000 \\
$\mathrm{~Pb}^{2+}, \mathrm{Ag}^{+}, \mathrm{Cl}^{-}, \mathrm{Br}^{-}$ & 750 \\
$\mathrm{Ba}^{2+}, \mathrm{Zn}^{2+}, \mathrm{Cu}^{+}, \mathrm{C}_{2} \mathrm{O}_{4}^{2-}, \mathrm{SO}_{4}{ }^{2-}$ & 500 \\
$\mathrm{Co}^{2+}, \mathrm{La}^{3+}, \mathrm{Cu}^{2+}, \mathrm{Ca}^{2+}, \mathrm{Mn}^{2+}, \mathrm{SO}_{3}{ }^{2-}$ & 250 \\
$\mathrm{Hg}^{2+}, \mathrm{NH}_{4}^{+}$ & 150 \\
$\mathrm{Zr}^{+4}, \mathrm{Fe}^{2+}$ & 50 \\
$\mathrm{Fe}^{3+}, \mathrm{Cd}^{2+}, \mathrm{Ni}^{2+}, \mathrm{PO}_{4}^{-3}$ & 25 \\
$\mathrm{Al}^{3+}, \mathrm{Cr}^{3+}$ & $<10$ \\
\hline
\end{tabular}




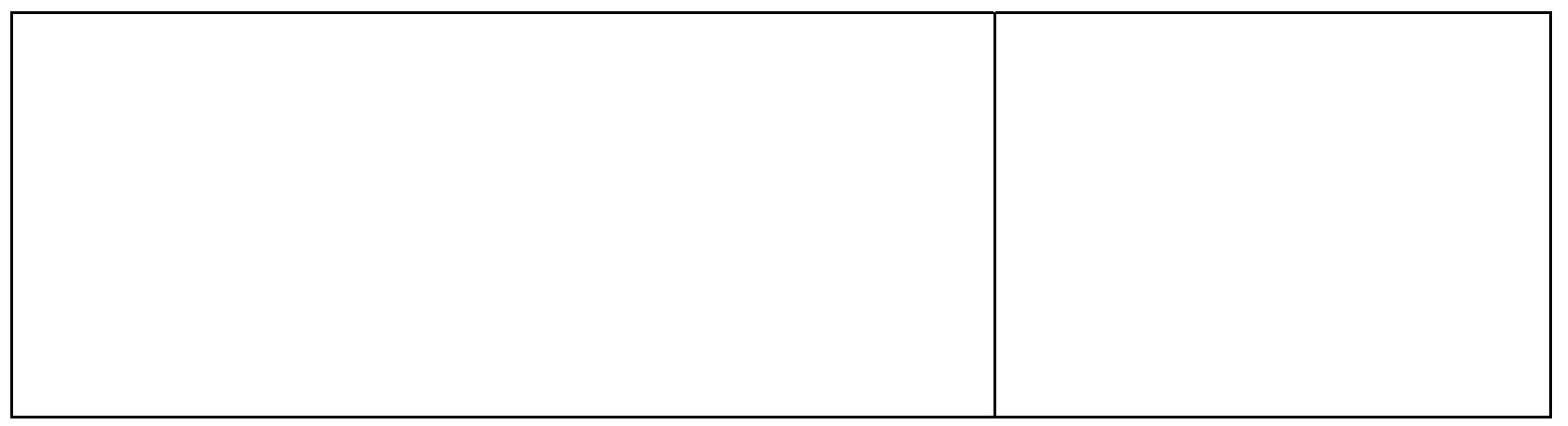

Also the effect of some foreign substances (e.g., glucose, lactose, starch and gum Arabic), that usually present in dosage forms are studied by adding different amounts of foreign substances to $100 \mu \mathrm{g}$ of bismuth. It is observed that the studied foreign species did not show any interference with the proposed method, Table (5).

Table 5 : Effect of additives and percipients on the determination of $100 \mu \mathrm{g}$ of $\mathrm{Bi}$ (III)

\begin{tabular}{|c|c|c|c|}
\hline Interferences & \multicolumn{3}{|c|}{ Recovery (\%) of $\mathbf{1 0 0} \boldsymbol{\mu g}$ Bi (III)/ $\mathbf{\mu g}$ of interferences } \\
\hline & $\mathbf{2 5 0}$ & $\mathbf{5 0 0}$ & $\mathbf{1 0 0 0}$ \\
\hline Glucose & 97.3 & 95.9 & 103.2 \\
\hline Lactose & 99.4 & 103.5 & 102.9 \\
\hline Starch & 101.2 & 103.5 & 103.5 \\
\hline Gum Arabic & 106.8 & Turbid & Turbid \\
\hline
\end{tabular}

\section{APPLICATIONS}

\section{Determination of Bi (III) in water and urine samples}

The proposed method has been successfully applied to the determination of bismuth(III) at two different concentrations added to appropriate volumes of tap, river, sea water and urine samples. The results are compiled in Table 6 and show that the proposed method is suitable for determining bismuth with satisfactory recovery.

Table 6 : Determination of Bi (III) in water and urine samples

\begin{tabular}{|c|c|c|c|}
\hline Sample & ml of sample & $\mathrm{Bi}(\mathrm{III})$ added $(\mu \mathrm{g})$ & Recovery* (\%) \\
\hline Tap water & $\begin{array}{l}2 \\
6\end{array}$ & $\begin{array}{l}50 \\
100 \\
50 \\
100\end{array}$ & $\begin{array}{l}98.1 \\
101.3 \\
101.5 \\
100.7 \\
\end{array}$ \\
\hline $\begin{array}{l}\text { River water } \\
\text { (Tigris river) }\end{array}$ & $\begin{array}{l}2 \\
6\end{array}$ & $\begin{array}{l}50 \\
100 \\
50 \\
100 \\
\end{array}$ & $\begin{array}{l}104.4 \\
102.9 \\
100.9 \\
102.0\end{array}$ \\
\hline
\end{tabular}




\begin{tabular}{|l|l|l|l|}
\hline & 2 & 50 & 101.0 \\
Sea water** & \multirow{2}{*}{6} & 100 & 102.3 \\
& 2 & 50 & 101.9 \\
& \multirow{2}{*}{ Urine } & 500 & 103.9 \\
\hline & \multirow{2}{*}{6} & 100 & 97.1 \\
& & 100 & 104.2 \\
& & & 96.8 \\
& &
\end{tabular}

*Average of three determinations

** The Mediterranean sea (Turkey)

\section{Determination of Bi (III) in a veterinary preparation}

The present method has also been applied to the determination of Bi (III) in veterinary preparation. The results are listed in Table 7, from which it can be concluded that the method is suitable for determining bismuth in the veterinary preparation sample with satisfactory recovery.

Table 7 : Determination of Bi (III) in veterinary preparation

\begin{tabular}{|c|c|c|}
\hline \multirow{2}{*}{ Veterinary preparation } & Bi(III) amount $(\boldsymbol{\mu g})$ & Recovery, (\%)* \\
\hline \multirow{2}{*}{$\begin{array}{c}\text { Diaclean } 2000 \mathrm{mg} \mathrm{Bi}_{5} \mathrm{O}(\mathrm{OH})_{9}\left(\mathrm{NO}_{3}\right)_{4} / \text { Sachet } \\
\text { Avico, Jordan }\end{array}$} & 50 & 95.3 \\
\cline { 2 - 3 } & 100 & 98.9 \\
\cline { 2 - 3 } & 150 & 96.5 \\
\hline
\end{tabular}

*Average of five determinations.

The performance of the proposed method was assessed by calculating the student's t-test compared with the literature method (Marczenko and Balecrzak, 2000). The results in Table 8 show that the calculated values of " $t$ " do not exceed the theoretical values at the 95\% confidence level (Christian, 2004) indicating that there is no significant difference in the precision between the proposed method and the reported method.

Table 8: Determination of bismuth by the proposed and literature methods

\begin{tabular}{|c|c|c|c|c|}
\hline \multirow[b]{2}{*}{ Veterinary preparation } & \multirow{2}{*}{$\begin{array}{c}\text { Bismuth } \\
\text { amount, } \mu \mathrm{g}\end{array}$} & \multicolumn{2}{|c|}{ Recovery, \%" } & \multirow[b]{2}{*}{ t. $\exp ^{* *}$} \\
\hline & & $\begin{array}{l}\text { Present } \\
\text { method }\end{array}$ & $\begin{array}{l}\text { Reported } \\
\text { Method }^{\#}\end{array}$ & \\
\hline \multirow{3}{*}{$\begin{array}{c}\text { Diaclean } 2000 \mathrm{mg} \\
\mathrm{Bi}_{5} \mathrm{O}(\mathrm{OH})_{9}\left(\mathrm{NO}_{3}\right)_{4} / \text { Sachet } \\
\text { Avico, Jorden }\end{array}$} & 50 & 95.3 & 98.6 & 1.29 \\
\hline & 100 & 98.9 & 99.3 & 0.13 \\
\hline & 150 & 96.5 & 98.9 & 0.69 \\
\hline
\end{tabular}

* Average of five determinations.

**Tabulated t-value at $95 \%$ confidence level and eight degree of freedom is 2.31 for $(n=10)$,

\# ( Marczenko and Balecrzak, 2004)

\section{CONCLUSION}

A simple, sensitive and accurate spectrophotometric method has been developed for the determination of bismuth(III) in aqueous solution, using alizarin red S (ARS) as 
chelating agent in the presence of $\mathrm{CPC}$ at $\mathrm{pH}$ 3. The method has been applied successfully to the determination of $\mathrm{Bi}(\mathrm{III})$ in natural water, urine and in a veterinary preparation.

\section{REFERENCES}

Afkhami, A.; Madrakian, T.; Siampour, H. (2006). Cloud point extraction spectrophotometric determination of trace quantities of bismuth in urine. J. Braz. Chem. Soc., 17 (4), 797-802.

Al-Hakeem, G.F.H.; Shakir, I.M.A. (2008). Study for the determination of bismuth(III) ion via chemiluminescence FIA using lucigenin and its application. M. Sc. Thesis, Baghdad University.

Amin, A.S. (2011). Cloud-point extraction and spectrophotometric determination of trace quantities of bismuth in environmental water and biological sample. J. Spect. Lett., 44 (6), 424 - 431.

Amir, M.A.; Karel, V. (2012). Determination of trace bismuth(III) by stripping voltammetry at antimony-coated carbon paste electrode. Int. J. Electrochem. Sci ., 7, 68-76.

Araki, Y.; Kagaya, S.; Sakai, K.; Matano, Y.; Yamamoto, K.; Okubo, T.; Tohda, K. (2008). Determination of $\mathrm{Al}, \mathrm{Cr}, \mathrm{Bi}, \mathrm{Fe}, \mathrm{Zn}, \mathrm{Cd}$ and $\mathrm{Pb}$ in crude drugs by inductively coupled plasma atomic emission spectrometry after coprecipitation with yttrium phosphate. J. Health Sci., 54(6), 682-685.

Barakat, S. A. (2002). Flow injection extraction - spectrophotometric determination of bismuth with di-(hydrogenated tallow alkyl) dimethylammonium chloride. Turk. J. Chem., 26, 345-349.

Chandrashekhar, P.M.; Mansing, A.A. (2008). Studies on liquid-liquid extraction and recovery of bismuth(III) from succinate media using 2-octylaminopyridine in chloroform. J. Chin. Chem. Soc. , 55, 807-817.

Christian, G.D. (2004). "Analytical Chemistry". John Wiley and Sons, 6th ed., Philadelphia, pp. 90-97.

Cui, F.; Wang, L.; Cui, Y. (2007). Determination of bismuth in pharmaceutical products using methyltriphenylphosphonium bromide as a molecular probe by resonance light scattering technique. J. Pharm. Biomed. Anal., 43 ( 30), 1033-1038.

Delevic, R. (1997). "Principles of Quantitative Chemical Analysis". Mc, Graw-Hill, Internatin-onal ed., Singapore, pp. 495-502.

Didi, M.A.; Sekkal, A.R.; Villemine, D. (2011). Cloud-point extraction of bismuth(III) with nonionic surfactants in aqueous solutions. Colloids and Surfaces A: Physicochem. Eng. Aspects, 375, 169-177.

Gaikwad, S.H.; Mahamuni, S.V.; Anuse, M.A. (2005). Extractive spectrophotometric determination of bismuth (III) in alloy sample using 1-amino-4, 4, 6-trimethyl $(1 \mathrm{H}, 4 \mathrm{H})$ pyrimidine-2-thiol. Indian J. Chem. Tech., 12, 365-368.

Gumus, G.; Filik, H.; Demirata, B. (2005). Determination of bismuth and zinc in pharmaceuticals by first derivative UV-Visible spectrophotometry. Anal. Chem. Acta., $\mathbf{5 4 7}$ (1), 138

Hargis, L.G. (1988). "Analytical Chemistry, Principles and Techniques". Prentice-Hall International, London, pp. 424-427. 
Hasdemir, E.; Karaboduk, K. (2010). Simultaneous determination of bismuth and copper by square wave voltammetry in the presence of ethylenediaminetetraacetic acid. G.U. J. Sci., 23(1), 33-39.

Honova, D.; Nemecove, I.; Suk, V. (1988). Spectrophotometric determination of bismuth and EDTA by means of the reaction of bismuth with pyrocatechol violet in the presence of septonex. Talanta, 35(10), 803-804.

Jan, K.; Anna, A.; Mariusz, S.; Wlodzimierz, R. (2007). Spectrophotometric determination of $\mathrm{Pb}(\mathrm{II}), \mathrm{Fe}(\mathrm{III})$ and $\mathrm{Bi}(\mathrm{III})$ in complexes with 1,2-diaminocyclohexane-N,N,N,Ntetraacetic acid (DACT). Polish. Pharm. Soc., 64(1), 3-8.

Jeronimo, P.C.A.; Araujo, A.N.; Montenegro, M.C.B.; Santinsky, D.; Solich, P. (2004). Colorimetric bismuth determination in pharmaceutical using a xylenol orange solgel sensor coupled to a multicommutated flow system. Anal. Chem. Acta, 504, 235241.

Ling, M.A.; Li-xin, Z.; Ling-ling, F.; Wen-zhang, L. (2005). Determination of trace bismuth in geological samples by hydride generation-atomic fluorescence spectrometry. Rock and Mineral Analysis, 24(3), 217-220.

Marczenko, Z.; Balecrzak, M. (2000). "Separation, Preconcentration and Spectrophotometry in Inorganic Analysis". Elsevier, pp. 114, 54-55, 116-118.

Nayan, S.G.; Bankim, J.S.; Shashi, P.K.; Ashwini, K.S. (2010). Potentiometric stripping analysis of bismuth based on carbon paste electrode modified with cryptand [2.2.1] and multiwalled carbon nanotubes. Electrochim. Acta, 56(2), 627.

Perrin, D.D. ; Dempsey, B. (1974). "Buffer for pH and Metal Ion Control". Chapman and Hall Ltd., London, pp. 129-131

Reddy, D.V.; Reddy, A.V. (2010). Amperometric determination of bismuth using gallacetophenone phyenylhydrazone with the structural elucidation of complex. E. J. Chem., 7(4), $1290-1295$.

Tzanavaras, P.D.; Themelis, D.G.; Economou, A. (2004). Sequential injection method for the direct spectrophotometric determination of bismuth in pharmaceutical products. Anal. Chem. Acta, 505(7), $167-171$.

Yamini, Y.; Chaloosi, M.; Ebrahim zadeh, H. (2002). Solid phase extraction and furnace atomic absorption spectrometric determination of ultra trace amounts of bismuth in water samples. Talanta, 56, $797-803$. 
Spectrophotometric Determination of Bismuth......... 